\title{
A QUALITATIVE EXPLORATION OF THE HOLY QURAN'S ENVIRONMENTAL TEACHINGS
}

\author{
Valentina-Mariana Manoiu $^{1 *}$, Ertan Düzgüneş ${ }^{2}$, Madani Azzeddine ${ }^{3}$ and Vasile-Sorin \\ ${ }^{1}$ Assoc. Prof. Dr., University of Bucharest, Faculty of Geography, ROMANIA, \\ valentina.mariana.manoiu@gmail.com \\ ${ }^{2}$ Asst. Dr., Karadeniz Technical University, School of Forestry, Department of Landscape \\ Architecture, TURKEY; ertanduzgunes@gmail.com \\ ${ }^{3}$ Assoc. Prof. Dr., University of Djilali Bounaama Khemis Miliana, Faculty of Social and Human \\ Sciences, ALGERIA; karim_1999_2000@yahoo.fr \\ ${ }^{4}$ Scientific Researcher Dr., National Institute of Research and Development for Biological \\ Sciences, Bucharest, ROMANIA, spagiricus@gmail.com
}

${ }^{*}$ Corresponding author

\begin{abstract}
The Holy Quran, the sacred Muslim religious book, is also a sum of principles and teachings covering all aspects of human life. About 750 verses (of 6236) refer to various aspects of nature, and to the relationship between man and nature. The aim of this paper is to briefly analyse some of the many ecological verses. The article highlights the eco-educational dimension of the Holy Quran by means of a qualitative investigation. It addresses the ecological considerations on the rational use of natural resources, ethical interactions between man and nature, and the rights of plants, animals and of the physical elements of the environment.
\end{abstract}

Keywords: the Holy Quran, environmental education, teachings, environmental protection, sustainability

\section{INTRODUCTION}

The sacred religious book of all Muslims, the Holy Quran, which contains 114 chapters (surah) and 6236 verses (ayah), also represents a sum of principles and teachings that cover all aspects of life and human activity. The Holy Quran contains religious concepts, ethical and spiritual conduct precepts, as well as rules and regulations for various aspects of everyday life. The Islamic way is to live a peaceful and harmonious life, individually, socially and ecologically.

For many centuries mankind has been unable to study certain information found in the Quran, as the scientific means available did not allow it. It was only in the twentieth century that people understood that many of the verses in the Quran were describing natural phenomena. Even today, without using specialized research, scientists have a hard time understanding the information available in the Quran. In order to understand some of the verses in the Quran, a scientist must hold encyclopaedic knowledge of many 
scientific disciplines. However, we have to keep in mind that this holy book remains first and foremost a religious book and we should not expect any actual scientific purpose or result from it. The fact that the verses of the Quran offer references to scientific knowledge which was (re)discovered and (re)affirmed 12001300 years later is a gift of this holy book.

One can identify in the Holy Quran numerous rules intended to protect nature and the environment. Approximately 750 verses of the Holy Quran refer to various aspects of nature, the relationship between man and nature, vegetal and animal organisms and their environment. In this holy book, there are advisements on reflecting over nature, on studying the links between organisms and their environment, on using our reason constructively in order to maintain the balance and proportions of nature.

One of the first teachings that the Quran brought to the Muslim people referred to the fact that this universe, with the Earth and the sky, where man lives, does not randomly exist, without any guidance or by the will of one single entity (Aminzadeh, 2013; Bateni, 2013; Bazzi, 2013; Karizi, 2013; Mozafari, 2013; Seda, 2002): „And if the Truth had followed their desires, verily the heavens and the earth and whosoever is therein had been corrupted. Nay, We have brought them their Reminder, but from their Reminder they now turn away." (23:71)

Still, the universe is organized by general laws which cannot be changed (Aminzadeh, 2013; Bateni, 2013; Bazzi, 2013; Karizi, 2013; Mozafari, 2013; Arbabi and Noormohamadi, 2014; Sharif, 1961), just as the Quran signals in the following verse: „(Shown in their) behaving arrogantly in the land and plotting evil; and the evil plot encloseth but the men who make it. Then, can they expect aught save the treatment of the folk of old? Thou wilt not find for Allah's way of treatment any substitute, nor wilt thou find for Allah's way of treatment aught of power to change." (35:43)

The environment is not our property and the human beings have the responsibility to take care of it and preserve it for all future generations (Arbabi and Noormohamadi, 2014; Kamaruzaman and Siti Akmar, 2011). The responsibility of man is not confined to one single generation, with everything having to be passed on in good condition from one generation to another. This sustainable approach has been supported in the Holy Quran approximately 1300 years before the best known and cited definition of sustainable development, presented in the Brundtland report (1987) of the World Commission on Environment and Development ("Sustainable development is aimed at the needs of the present, without compromising the ability of future generations to address theirs"): "Who hath appointed the earth a resting-place for you, and the sky a canopy; and causeth water to pour down from the sky, thereby producing fruits as food for you. And do not set up rivals to Allah when ye know (better)." (2:22)

The objective of this paper is to highlight the role of the Holy Quran in environmental education, briefly noting and analysing some of the many verses on ecology and selecting the ones which educate people on the importance of the environment and on the importance of taking responsibility to preserve it for future generations. The article stresses the eco-educational dimension of the Holy Quran by investigating the qualitative content of its verses. We can conclude that there is a pattern of environmental ethics based on the right to respect all of nature's elements, living or non-living.

\section{MATERIALS AND METHODS}

The present study is a qualitative and descriptive-analytic investigation of the Holy Quran. It addresses the ecological considerations on the rational use of natural resources, ethical interactions between man and nature, as well as the rights of plants, animals and all other non-living elements of the environment. Moreover, the study analyses (what we referred to as) "the green verses", in order to highlight the ecological calibre of the Holy Quran, in today's environmentally-troubling context. The Holy Quran transcends space, time and events, proving through every verse its quality as an all-around guidance pillar, including for nature lovers and environment defenders.

The Romanian translation of the Holy Quran, the third edition, translated by the Islamic and Cultural League of Romania (2004) and published by the Islam Publishing House, and also the online translations of Quran have been used for this study. In all references to the Quran in this paper, the first number refers to the surah (chapter) and the second to the ayah (verse) - e.g. 2:22.

\section{RESULTS AND DISCUSSIONS}

The teachings of the Holy Quran support moderation of the human behaviour in order to avoid excesses. This moderation can be described through three principles found throughout its pages: the principles of unity, balance and responsibility. 


\subsection{The Principle of Unity}

The Holy Quran shows that nature is a whole, a complete and complex system the components of which support and protect each other. If one of the components is affected, it disturbs the order and normal function of the entire system - of nature (Aminzadeh, 2013; Bateni, 2013; Bazzi, 2013; Karizi, 2013; Mozafari, 2013; Kamaruzaman and Siti Akmar, 2011; Aş-Şarif, 2011; Osman, 2012). In this respect, the Holy Quran has encouraged a holistic approach on the environment approximately 1300 years before the emergence of the academic term of holism that has been defined by Smuts (1926): „And the sky He hath uplifted; and $\mathrm{He}$ hath set the measure that ye exceed not the measure." (55:7-8)

All nature is one. Its elements interrelate and form a whole. Mankind has been given all the needed resources to live (Aminzadeh, 2013; Bateni, 2013; Bazzi, 2013; Karizi, 2013; Mozafari, 2013; Arbabi and Noormohamadi, 2014; Sharif, 1961; Aş-Şarif, 2011; Osman, 2012; Miller, 1992). He must use them wisely and he has no right to abuse them (Aminzadeh, 2013; Bateni, 2013; Bazzi, 2013; Karizi, 2013; Mozafari, 2013; Aş-Şarif, 2011; Osman, 2012): „Who hath appointed the earth as a bed and hath threaded roads for you therein and hath sent down water from the sky and thereby We have brought forth divers kinds of vegetation, (Saying): Eat ye and feed your cattle. Lo! herein verily are portents for men of thought." (20:5354)

The 164th verse of the 2nd Surah and the 10th verse of the 55th Surah synthesize the same principle. People must manage wisely all of nature's gifts and at the same time get to know nature, its elements, its processes and their roles, in order to better understand it and respect it (Aminzadeh, 2013; Bateni, 2013; Bazzi, 2013; Karizi, 2013; Mozafari, 2013; Arbabi and Noormohamadi, 2014; Kamaruzaman and Siti Akmar, 2011; Aş-Şarif, 2011; Osman, 2012; Miller, 1992): „Lo! In the creation of the heavens and the earth, and the difference of night and day, and the ships which run upon the sea with that which is of use to men, and the water which Allah sendeth down from the sky, thereby reviving the earth after its death, and dispersing all kinds of beasts therein, and (in) the ordinance of the winds, and the clouds obedient between heaven and earth: are signs (of Allah's Sovereignty) for people who have sense.” (2:164); „And the earth hath He appointed for (His) creatures." (55:10)

\subsection{The Principle of Balance}

The universe exists in perfect balance and proportion, both qualitatively and quantitatively (Aminzadeh, 2013; Bateni, 2013; Bazzi, 2013; Karizi, 2013; Mozafari, 2013; Aş-Şarif, 2011; Osman, 2012; Islam, 2004) „Lo! We have created everything by measure." (54:49)...,the heavens and the earth with truth. Lo! therein is indeed a portent for believers." (29:44)...,And the sky He hath uplifted; and He hath set the measure." (55:7)

Man is obliged to respect the environment: „Assuredly the creation of the heavens and the earth is greater than the creation of mankind; but most of mankind know not." (40:57)

All the components of the universe have a well-established role. As part of the environment, man has his role as well - as its wise user and protector - and the non-compliance to this role leads to imbalance (Arbabi and Noormohamadi, 2014; Akhtar, 1996).

\subsection{The Principle of Responsibility}

According to Islam, man is not the master of nature and world. Man is responsible for his behaviour (Aminzadeh, 2013; Bateni, 2013; Bazzi, 2013; Karizi, 2013; Mozafari, 2013; Kamaruzaman and Siti Akmar, 2011; Aş-Şarif, 2011; Osman, 2012; Islam, 2004): „Lo! We offered the trust unto the heavens and the earth and the hills, but they shrank from bearing it and were afraid of it. And man assumed it. Lo! he hath proved a tyrant and a fool." (33:72)

Man is the gardener of the Earth (Arbabi and Noormohamadi, 2014; Kamaruzaman and Siti Akmar, 2011; Aş-Şarif, 2011; Osman, 2012): „And when thy Lord said unto the angels: Lo! I am about to place a viceroy in the earth, they said: Wilt thou place therein one who will doharm therein and will shed blood, while we, we hymn Thy praise and sanctify Thee? He said: Surely I know that which ye know not." (2:30)

Man must be aware of his responsibility on this Earth, as he is only a temporary administrator - a beneficiary and NOT an owner (Arbabi and Noormohamadi, 2014; Kamaruzaman and Siti Akmar, 2011; Aş-Şarif, 2011; Osman, 2012): „But seek the abode of the Hereafter in that which Allah hath given thee and neglect not thy portion of the world, and be thou kind even as Allah hath been kind to thee, and seek not corruption in the earth; lo! Allah loveth not corrupters." (28:77)

The Quran encourages the protection of all the natural elements of the environment (Kamaruzaman and Siti Akmar, 2011; Aş-Şarif, 2011; Osman, 2012). The Holy Quran specifies that people are not superior to any 
other species: „There is not an animal in the earth, nor a flying creature flying on two wings, but they are peoples like unto you. We have neglected nothing in the Book (of Our decrees). Then unto their Lord they will be gathered." (6:38)

The Holy Quran mentions that there is a close relationship between the behaviour of people and the state of the environment (Aminzadeh, 2013; Bateni, 2013; Bazzi, 2013; Karizi, 2013; Mozafari, 2013; Kamaruzaman and Siti Akmar, 2011). A righteous and moral behaviour will lead to positive results: „And if the people of the townships had believed and kept from evil, surely We should have opened for them blessings from the sky and from the earth. But (unto every messenger) they gave the lie, and so We seized them on account of what they used to earn." (7:96); "And, O my people! Ask forgiveness of your Lord, then turn unto Him repentant; He will cause the sky to rain abundance on you and will add unto you strength to your strength. Turn not away, guilty!" (11:52)

The Quran sends out a clear message to take good care of the environment and protect it, as humankind is not its owner! Moreover, the Quran prohibits cruelty to animals and birds. It is man's responsibility to ensure the wellbeing of all creation. In other words, the attitude of Islam towards the environment and natural resources is a constructive one, based on protection and development, dismissing all abuse and destruction (Aminzadeh, 2013; Bateni, 2013; Bazzi, 2013; Karizi, 2013; Mozafari, 2013; Arbabi and Noormohamadi, 2014; Aş-Şarif, 2011; Osman, 2012). These issues are highlighted in the 11th Surah, which refers to maintaining and restoring the lands through agriculture, cultivation and construction: "... $\mathrm{O}$ my people! Worship Allah, you have no god but Him. It is HeWho created you from the Earth and made it a dwelling place foryou." (11:61); "And thus have We willed you to be a community of the middle way, so that (with your lives) you might bear witness to the truth before all manking..." (2:143)

Therefore, the right to use natural resources implies humankind's commitment to preserve life and the natural resources in a manner which will ensure that the next generations will also enjoy their benefits, appreciate their beauty and use them to build their homes - all of which will have to be done in a moderate and considerate way (Aminzadeh, 2013; Bateni, 2013; Bazzi, 2013; Karizi, 2013; Mozafari, 2013; Arbabi and Noormohamadi, 2014; Kamaruzaman and Siti Akmar, 2011; Mohammadi, Najjarzadegan and Masoumbeigi, 2013).

Environmental protection and nature conservation represent the philosophy of the Islamic environmentalism (Aminzadeh, 2013; Bateni, 2013; Bazzi, 2013; Karizi, 2013; Mozafari, 2013; Arbabi and Noormohamadi, 2014; Mohammadi, Najjarzadegan and Masoumbeigi, 2013). As the administrator of nature, man has the duty to take care of environmental sustainability and to oppose waste: "O Children of Adam! Look to your adornment at every place of worship, and eat and drink, but be not prodigal. Lo! He loveth not the prodigals." (7:31)

"He it is Who produceth gardens trellised and untrellised, and the date-palm, and crops of divers flavour, and the olive and the pomegranate, like and unlike. Eat ye of the fruit thereof when it fruiteth, and pay the due thereof upon the harvest day, and be not prodigal. Lo! Allah loveth not the prodigals." (6:141)

Over the following section, we will present some of the many eco-verses and their teachings on the various environmental elements.

\subsection{Water}

It is the basis of life itself. It is the miraculous liquid that sustains life: „Have not those who disbelieve known that the heavens and the earth were of one piece, then We parted them, and we made every living thing of water? Will they not then believe?" (21:30)

Several verses in the Holy Quran refer to the water cycle and its fundamental role in sustaining life on Earth (Aş-Şarif, 2011; Osman, 2012; Bucaille, 1995; Keshavarz, 2010).

„And thou (Muhammad) seest the earth barren, but when We send down water thereon, it doth thrill and swell and put forth every lovely kind (of growth)." (22:5)

Aside from its role in supporting life, for Islam (as well as for all the other religions across the globe), water has a socio-religious function, purifying the body and clothes (Aş-Şarif, 2011; Osman, 2012; Islam, 2004).

The Islamic culture forbids any sort of waste, including water (Aş-Şarif, 2011; Osman, 2012; Islam, 2004). The Holy Quran gets the point across in a very clear manner: „O Children of Adam! Look to your adornment at every place of worship, and eat and drink, but be not prodigal. Lo! He loveth not the prodigals." (7:31)

The water circuit is well known today. The verses of the Holy Quran related to the water circuit express ideas which are utterly obvious in today's world, but we need to keep in mind the reality of the time when the 
revelation and writing of the Holy Quran occurred, a time when the only known practice was land irrigation (Aş-Şarif, 2011; Osman, 2012; Bucaille, 1995). Verse 21 of the 39th Surah mentions: „Hast thou not seen how Allah hath sent down water from the sky and hath caused itto penetrate the earth as water springs, and afterward thereby produceth crops of divers' hues; and afterward they wither and thou seest them turn yellow; then He maketh them chaff. Lo! herein verily is a reminder for men of understanding." (39:21)

Such ideas are common today, but we do have to keep in mind the fact that it was only in the XVIth century that Bernard Palissy put together the first coherent description of the water circuit (Bucaille, 1995; Verry, 2003). If someone were to compare the notions of modern hydrology and the information available in the Quran on the matter, the consensus between them would be undeniable.

There are also certain verses with easily understandable ideas, which at the same time hide amazing scientific facts. A good example is the 30th verse of the 21st Surah: „Have not those who disbelieve known that the heavens and the earth were of one piece, then We parted them, and we made every living thing of water? Will they not then believe?" (21:30) This is a spectacular statement of the modern idea claiming that the origin of life is aquatic. Water is at the origin of all of the life forms on Earth (Bucaille, 1995; Keshavarz, 2010).

All living beings are made of water. The body of the average adult person is made up of $70 \%$ water. The Islamic teachings describe the sacred qualities of water: life-giving, life-sustaining and purifying, an idea also presented in the following verse (Bucaille, 1995): „He it is Who sendeth down water from the sky, and therewith We bring forth buds of every kind; We bring forth the green blade from which We bring forth the thick-clustered grain; and from the date-palm, from the pollen thereof, spring pendant bunches; and (We bring forth) gardens of grapes, and the olive and the pomegranate, alike and unlike. Look upon the fruit thereof, when they bear fruit, and upon its ripening. Lo! herein verily are portents for a people who believe." (6:99)

The word water is found numerous times in the Holy Quran, which repeatedly praises the life-giving properties of water: "Seest thou not how Allah sendeth down water from the sky and then the earth becometh green upon the morrow? Lo! Allah is Subtile, Aware.” (22:63); „And He it is Who sendeth the winds, glad tidings heralding His mercy, and We send down purifying water from the sky.” (25:48); „And We send down from the sky blessed water whereby We give growth unto gardens and the grain of crops." (50:9)

\subsection{Air}

It is just as important as water. Most of the living beings on Earth depend on the air they breathe to survive. Given all the functions fulfilled by the atmosphere, it is obvious that keeping it balanced, pure and unpolluted is essential for preserving life (Aş-Şarif, 2011; Osman, 2012; Islam, 2004).

„And $\mathrm{He}$ it is Who sendeth the winds as tidings heralding His mercy, till, when they bear a cloud heavy (with rain), We lead it to a dead land, and then cause water to descend thereon and thereby bring forth fruits of every kind. Thus bring We forth the dead. Haply ye may remember." (7:57)

A serious issue arising from air pollution is represented by acid rain, which kills lakes and rivers, destroys the soil and threatens human, plant and animal life. The main pollutants that contribute to acid rain are sulphur dioxide and nitrogen dioxide. The following verse of the Holy Quran refers to this particular aspect of pollution - acid rain (Aş-Şarif, 2011; Osman, 2012; Islam, 2004): „Have ye observed the water which ye drink? Is it ye who shed it from the raincloud, or are We the Shedder? If We willed We verily could make it bitter. Why then, give ye not thanks?" (56:68-70)

\subsection{Earth}

We came from it and we will return to it (Aş-Şarif, 2011; Osman, 2012). „And Allah hath made the earth a wide expanse for you, That ye may thread the valley-ways thereof." (71:19-20)

„And Allah hath caused you to grow as a growth from the earth, And afterward He maketh you return thereto, and He will bring you forth again, a (new) forthbringing." (71:17-18)

Fertile ground is the foundation for crops, which represent some of the food supply for man and other beings (Aş-Şarif, 2011; Osman, 2012). „Therewith He causeth crops to grow for you, and the olive and the datepalm and grapes and all kinds of fruit. Lo! herein is indeed a portent for people who reflect." (16:11)

Reducing the soil productivity, exposing it to erosion, as well as uncontrolled exploitation are all actions taken against the general natural balance and they are forbidden by Islam (Aş-Şarif, 2011; Osman, 2012; Islam, 2004). 
Not only does Prophet Muhammad encourage the sustainable use of fertile lands, but He also talks about the benefits of transforming unused lands into productive ones (Aş-Şarif, 2011; Osman, 2012; Islam, 2004): "That We may give life thereby to a dead land, and We give many beasts and men that We have created to drink thereof." (25:49)

\subsection{Plants}

They are sources of food, sources of oxygen, soil-enrichment forms, they protect lands from soil erosion with their roots, they absorb and retain water, they are the starting point for medicine, perfume, hygienic items, fuel, etc.

Plants are of different species, kinds and colours, traits which have been mentioned more than 1000 years before the notion of "species" was first introduced in Historia plantarum, John Ray's paper from 1686 (AşŞarif, 2011; Osman, 2012; Bucaille, 1995; Ray, 1686): „And whatsoever He hath created for you in the earth of divers hues, lo! therein is indeed a portent for people who take heed.” (16:13); „And cause the grain to grow therein, And grapes and green fodder, And olive-trees and palm-trees, And garden-closes of thick foliage, And fruits and grasses: Provision for you and your cattle." (80:27-32)

All Muslims must bring their contribution to enlarging green areas. Taking care of the environment is not only an obligation for Muslims, but also an important form of pay-back (Aş-Şarif, 2011; Osman, 2012; Islam, 2004). The Prophet Muhammad said, "If a Muslim plants a tree or sows seeds, and then a bird, or a person or an animal eats from it, it is regarded as a charitable gift (sadaqah) for him." (Khan, 1994, Hadith 1071; AlBukhari, 1999, Hadith 2320; Muslim, 1998, Hadith 3969; Borhan and Ab.Aziz, 2009).

In order to further stress the importance of taking care of green areas, the Prophet also said: "If the Hour (the day of Resurrection) is about to be established and one of you was holding a palm shoot, let him take advantage of even one second before the Hour is established to plant it." (Morrow, 2014)

On a global level, in the time of Prophet Muhammad, botany was not advanced enough for scientists to know that plants have both female and male reproductive organs (Aş-Şarif, 2011; Osman, 2012; Bucaille, 1995). Still, the 20th surah mentions the following: "Who hath appointed the earth as a bed and hath threaded roads for you there in and hath sent down water from the sky and thereby We have brought forth divers kinds of vegetation." (20:53)

Nowadays we know that the fruit comes from plants with reproductive organs. The 13th surah says: „And He it is Who spread out the earth and placed therein firm hills and flowing streams, and of all fruits He placed there in two spouses (male and female)." (13:3)...meaning two varieties or a pair made up of a male and a female.

\subsection{Animals}

Animals do not only represent a source of food and various goods. Due to their enhanced senses and their ability to develop social relations, animals have a special status in Islam. In the Holy Quran, they are considered communities, similar to the ones of humans (Aş-Şarif, 2011; Osman, 2012; Islam, 2004): „There is not an animal in the earth, nor a flying creature flying on two wings, but they are peoples like unto you." (6:38)

Muslims believe that animals deserve respect and that people must also show compassion to animals. A Muslim has to provide food or water for a thirsty or hungry animal. The Prophet said: "There will be a reward for helping them;" (Khan, 1994, Hadith 1094; Rahman and Aidaros, 2012; Atoom and Abu-Shrakh, 2014) ...,Those not showing mercy, will not be shown mercy." (Khan, 1994, Hadith 2020)

One story talks about one of the Prophet's travels, when he came across a bird whose chicks had been taken away. He asked "Who disturbed the bird and took its' chickens?" and then asked for them to be brought back (Atoom and Abu-Shrakh, 2014).

Muslims must show kindness to animals, even when they are about to sacrifice them. There are very strict Islamic rules for sacrificing an animal. A Muslim is not allowed to torment an animal, beating it, burdening it with more than it can carry, mutilating it, burning it, etc.

Uqba ibn Nafi (622-683), an Arab general that served the Umayyad dynasty, narrated that the Prophet said: "A woman entered the (Hell) Fire because of a cat which she had tied, neither giving it food nor setting it free to eat from the vermin of the earth." (Atoom and Abu-Shrakh, 2014)

To live a life according to the Islamic principles means letting go of any extravagance and living harmoniously with everything that surrounds us, as well as showing compassion for all other elements of 
nature (Aş-Şarif, 2011; Osman, 2012; Islam, 2004).

\subsection{The importance of environmental balance}

The environment in which we live is a chain of links that influence each other in such a way that any imbalance felt by one of them will bring a negative influence on all others. This was recently proven by environmental sciences (the concept of ecological balance is relatively new, introduced in the late 20th century (United Nations, 1997) and it was also pointed out by the following verses of the Holy Quran (Akhtar, 1996): „And the earth have We spread out, and placed therein firm hills, and caused each seemly thing to grow therein.” (15:19); „Lo! We have created everything by measure.” (54:49); „He unto Whom belongeth the Sovereignty of the heavens and the earth, $\mathrm{He}$ hath chosen no son nor hath $\mathrm{He}$ any partner in the Sovereignty. He hath created everything and hath meted out for it a measure." (25:2)

The billions of galaxies in the universe, the billions of creatures on Earth, everything that has ever been created, from the smallest particle of the atom and up to the biggest of galaxies, they are all part of a perfectly-created system where all the elements find themselves interdependent, influencing each other in a positive or negative way. Each being has its predestined function, which must remain undamaged and respected (Seda, 2002; Arbabi and Noormohamadi, 2014; Aş-Şarif, 2011; Mohammadi, Najjarzadegan and Masoumbeigi, 2013): „We created not the heaven and the earth and all that is between them in play.” (21:16)

And if other beings have been tamed to serve mankind, the Quran brings certain conditions to these actions (Arbabi and Noormohamadi, 2014; Mohammadi, Najjarzadegan and Masoumbeigi, 2013): „Lo! a clear proof hath come unto you from your Lord; so give full measure and full weight and wrong not mankind in their goods, and work not confusion in the earth after the fair ordering thereof. That will be better for you, if ye are believers.” (7:85); „Eat and drink of that which Allah hath provided, and do not act corruptly, making mischief in the earth." (2:60); „And the sky He hath uplifted; and He hath set the measure, That ye exceed not the measure." (55:7-8)

\section{CONCLUSION}

Everything on this planet was created wisely with a purpose: „Lo! We have created everything by measure.” (54:49)

The Holy Quran mentions that man must not change anything in this natural order: „Work not confusion in the earth after the fair ordering (thereof) and call on Him in fear and hope. Lo! the mercy of Allah is nigh unto the good." (7:56) Still, all the damages brought upon the environment have been caused by man. The environmental and ecological disasters, as well as human intervention have been vividly recounted in the Holy Quran: „Corruption doth appear on land and sea because of (the evil) which men's hands have done, that He may make them taste a part of that which they have done, in order that they may return." (30:41)

When the concept of environment is assessed on the axis of the Holy Quran, it becomes apparent that the Holy Book has produced significant and permanent solutions for a wide range of environmental problems, i.e. it has put forth principles contributing to environmental protection.

The environmental teachings are obvious in the verses of the Holy Quran. In order to ensure a healthy environment, these teachings must be respected and put into practice on every level. As a conclusion, we can say that the Prophet Muhammad could be considered a pioneer of environmentalism, preservation, sustainable development and resource management.

\section{REFERENCES}

Akhtar RM. Towards an Islamic Approach for Environmental Balance. Islamic Economic Studies, 1996; 3-2. p. 57-76.

Al-Bukhari M. Sahih al-Bukhari - "Kitab al-Harth wa al-Muzara'ah". Riyadh: Dar al-Salam; 1999. Hadith No.2320. p.372.

Aminzadeh B. Religious Ideology and Environment - An Introduction to Islamic Approach to Nature, Islam and Environment. Hekmat Quarterly Journal. An International Journal of Academic Research. Sixth Issue 2013; p.17-32.

Arbabi M, Noormohamadi MR. Evaluating the Situation and Rights of Environment in Islamic Lifestyle, From the Viewpoint of Quran and Narrations. Islam Life Center Health 2014; 1:4. p. 1-7.

Aş-Şarif A. Ştiinţele despre Pământ în Coran; 2011. http://islamromania.ro/art- 
470/referiri_in_coran_la_stiinta_mediului.html.

Atoom MS, Abu-Shrakh SD. The Educational Assistants in the Holy Quran (graphic, figuration, depiction). Analytic study. International Journal of Academic Research in Education and Review2014; 2:9. p. 231241.

Bateni I. Preservation of environment in Islamic teachings, Islam and Environment. Hekmat Quarterly Journal. An International Journal of Academic Research. Sixth Issue 2013; p.33-46.

Bazzi K. A Reflection on Sustainable Environment in Islamic World, Islam and Environment. Hekmat Quarterly Journal. An International Journal of Academic Research. Sixth Issue 2013; p.77-96.

Borhan JT, Ab. Aziz MR. Agriculture And Agribusiness From The Perspective Of Al-Qur'an And AlSunnah. Jurnal Usuluddin 2009; 30, p.325-344.

Bucaille M. Coranul și Știința Modernă. Centrul Informaţional Islamic, Dubai - E.A.U; 1995.

Islam MM. Towards a Green Earth: an Islamic Perspective. Asian Affairs 2004; 26:4, p. 44-89.

Kamaruzaman J, Siti Akmar AS. Environmental Sustainability: What Islam Propagates. World Appl. Sci. J. (Special Issue on Creating a Knowledge Based Society) 2011; 12, p. 46-53.

Karizi M. Religions and Environment, Islam and Environment. Hekmat Quarterly Journal. An International Journal of Academic Research. Sixth Issue 2013; p. 47-60.

Keshavarz S. Quran point of view on dimensions of reflection and its indications in education system. Procedia Social and Behavioral Sciences 2010; 9, p. 1812-1814.

Khan MM. Summarized Sahih Al-Bukhari Arabic-English. Riyadh - Saudi Arabia: Maktaba Dar-us-Salam Publishers \& Distributors; 1994; Hadith No.1071. p.505.

Miller G. The Amazing Quran. Abul-Qasim Publishing House; 1992. https://ia700801.us.archive.org/12/items/TheAmazingQuran.pdf/TheAmazingQuran.pdf.

Mohammadi NM, Najjarzadegan F, Masoumbeigi H. Evaluating the Relation Between God and Universe, and Its Role in Promotion of Environmental Ethics From the Viewpoint of Quran. Islamic Lifestyle Centered on Health 2013; 1:3, p. 54-60.

Morrow JA. Islamic Images and Ideas. Essays on Sacred Symbolism. Jefferson, North Carolina and London: McFarland \& Company Inc. Publishers; 2014.

Mozafari MH. The Fundamentals of Sustainable Utilization of Natural Resources According to the Quran, Islam and Environment. Hekmat Quarterly Journal. An International Journal of Academic Research. Sixth Issue 2013; p. 61-76.

Muslim AH. Sahih Muslim. "Kitab al-Musaqat wa al-Muzara'ah". Riyadh: Dar al-Salam; 1998. Hadith No. 3969. p. 679.

Osman M. Islamul si ecologia; 2012. https://ecologiesireligie.wordpress.com/2012/02/13/mohamed-osmanislamul-si-ecologia/.

Rahman SA, Aidaros $\mathrm{H}$. Islam and animal welfare with special reference to cruelty to animals during transport and slaughter. Journal of Commonwealth Veterinary Association2012; 28:2, p. 27-30.

Ray J. Historia plantarum. Londini:Typis Mariae Clark. prostant apud Henricum Faithorne; 1686. https://ia800303.us.archive.org/6/items/Historiaplantar2RayJ/Historiaplantar2RayJ.pdf.

Report of the World Commission on Environment and Development: Our Common Future (Brundtland Report); 1987. http://www.un-documents.net/our-common-future.pdf.

Seda P. Islam is...; 2002.

Sharif MM. A History of Muslim Philosophy, With short accounts of other Disciplines and the Modern Renaissance in the Muslim Lands. Institute of Islamic Culture, Pakistan Philosophical Congress; 1961.

Smuts JC. Holism and Evolution. New York: The Macmillan Company; 1926. https://archive.org/details/holismevolution00smut.

The Holy Quran. http://read.quranexplorer.com/1/1/1/Usmani/Mishari-Rashid/Eng-Pickthal-Audio/Tajweed- 
OFF.

The Holy Quran. Traducerea sensurilor Coranului cel Sfant in limba romana. Islamic and Cultural League of Romania. Islamic Publishing House; 2004. http://islamhouse.com/ro/books/108313/.

United Nations. Glossary of Environment Statistics. Studies in Methods 1997; F:67.

Verry ES. Ground Water and Small Research Basins: An Historical Perspective. GROUND WATERWatershed Issue 2003; 41:7, p.1005-1007. http://info.ngwa.org/gwol/pdf/032179280.pdf. 